Die serbische Reaktion darauf in wissenschaftlichen Kreisen ist absehbar, man zeigt kein Verständnis dafür, warum das Fundament einer gemeinsamen Schriftsprache, an dem die serbische Seite entscheidend beteiligt war, nicht mit einem entsprechenden Attribut versehen werden soll. Im Ergebnis wäre nach Ansicht der Autoren alles andere als das Lingonym „Serbisch“ für die postulierte polyzentrische Varietät unlogisch.

Es lässt sich drittens festhalten, dass es sich um eine wichtige Publikation handelt, die Einblicke in den štokavischen Sprachraum aus serbischer Perspektive gibt und argumentativ darlegt, warum bestimmte Affinitäten in der gesamten Region nach wie vor eine zentrale Rolle spielen. Die Kyrilliza und ihre kulturhistorische Bedeutung werden angesprochen und es bleibt unbedingt zu wünschen, dass die hier präsentierten Einzelbeiträge auch als Denkanstoß interpretiert werden und Gehör finden, in erster Linie in Serbien selbst. Schließlich liegt es in den Händen der Politik, regulierend zu wirken und dabei abzuwiegen, welcher Weg tatsächlich im Interesse der Einwohner des Landes und der nächsten Generation ist und welche konkreten Maßnahmen ergriffen werden sollten, um dem so wichtigen Ziel des Sprachschutzes ein Stück näher zu kommen. Ein wichtiger Schritt war daher sicher die Декларација о очуваюу срйской језика и културе von 2018, aber wird sie wirklich einen Durchbruch auf allen Ebenen markieren können? Jedenfalls sollte die eindeutige Meinung zu dem Thema aus akademischen Kreisen auch in Zukunft berücksichtigt werden, denn sie könnte als wichtige Richtschnur für weitere Entscheidungen dienen.

Martin Henzelmann

\title{
Bibliografie:
}

KUSTURICA, E. (ed.): Srpski jezik i ćirilica danas: zbornik radova. Andrićgrad: Andrićev institut, 2017.

\section{A Unique Multiperspective and Multidisciplinary Insight into the Issue of Global Communication}

ЗЕРНЕЦЬКА, О.: Глобальна комунікація. Київ: Наукова думка, 2017. 350 р.

About the author: Olga Zernetska is Professor, Dr. Hab. in Communication and Political Studies, head of the Department of Global and Civilization Problems of the Institute of World History of the National Academy of Sciences of Ukraine; the author of 5 individual monographs, 30 collective monographs and 300 scientific articles 
presented in Ukrainian, English, French, Spanish, Korean and Russian languages; fields of interest: global development and global communication, cybersecurity, global culture, traditional and new media, discourse analyses, especially political discourse and elections; e-mail: olga.zernetska@gmail.com.

In her latest monograph "Global Communication" Olga Zernetska focuses on the issues of digital revolution that enhances globalization processes in all spheres of human activity. In it she demonstrates that digital communication becomes a mighty engine of all global and civilization processes as such being also the basic factor of the globalization of the 21st-century. In fact, satellite communication, Internet, social nets, mobile telephony, electronic financial markets, e-business, e-government, e-elections and many other innovations in contemporary life of mankind is the foundation of the current global society. It is simply impossible to understand the current history of the 21st-century and its civilization perspective without these trends. Moreover, together with these trends there come newly emerging and so unexperienced before complex problems of a different kind that need to be explored and solved. No wonder this original innovative interdisciplinary research by Olga Zernetska presented in the Ukrainian language can draw the attention of a wide readership in the Slavic research community and beyond.

The 1st chapter gives a historic overview to the topic covering the issues that goes together with both the history and theory of global communication development. The author detects the history from the ancient times to nowadays paying a special attention to less researched periods of global communication such as the development of telegraph in the middle of the 19th century and laying transatlantic and then transpacific cables by the Great Britain. Paying attention to the breakthrough of information, communication, just as financial, economic, and social significance of this technological breakthrough, a thorough examination of the political aspects of the technology is given. It was the innovation that strengthened the might and power of the British Empire in many ways. Coming to nowadays technology and, specifically, analyzing the transatlantic, transpacific and other cables of the beginning of the 21st century that constitute the mighty global underwater information-communication Net, the author stresses that $90 \%$ of information-communication traffic are running through it now and, as the author specifies, only $10 \%$ are distributing through satellites. Within the rise of the network society, there comes the analysis of the technology, law, and policy of international satellite, the geopolitics of the satellite industry, international competition between satellite and fiber optic carriers, just as the development and impact of communication satellites. The author considers it important to observe the history of the satellite development within information, communication and investigation needs of the countries of the East and West blocks from the 1970s up till now. Such a trend as commercialization of satellites is also discussed together 
with opening the possibility for mighty companies and rich individuals to buy special information from DBS satellites (from photos of different parts of the world to other confidential information).

The author explores the works of the leading scholars in this sphere of science-M. Castells, N. Chomski, M. McQuail, X. Mowlana, I. Volkmer, M. Albrow, A. Aparadurai, C. Hayden, R. Merton, T. Kun, I. H. Shiller, E. M. Rogers and many others. The state of theoretical thought in its evolution of the methodological paradigms of global communication development is considered with a focus on its increasing role in establishing new world order at the beginning of the third millennium. The main concepts of global communication (communication science, globalization, international communication, transnational communication, global communication, communications together with sovereignty, global culture, Internet, oligopoly, interaction, elite, dominant discourse intertextuality, dominant paradigm and many others) are explored as they are defined by foreign scholars in this field. The concept of global communication being in the center of discussion is represented with 15 definitions given by researchers from America, Australia, Asia and Europe.

In the 2nd chapter the author dwells on such essential questions of global communication as national identity, the rise and spread of global culture, the main actors of global communication, the typology of global mediacracy and the expansion of the media empires. Zernetska reveals complex and multi-componential processes taking place in humanitarian domains at the end of the 2oth - beginning of the 21st centuries (the period when global transformations have obtained a distinctive character, have become the object of scholarly description, analysis and prognosis demanding interdisciplinary approach. She views interdisciplinarity to be productive as globalization changes the life of the individuals, their sensing the world, experience and cultural identity of different nations. Rapid development of information-communication systems, as the author observes, become still more asymmetrical, going prevalently from North to South. The processes of concentration and conglomeration, transnationalization and internationalization of the information agencies, global media empires and other industries of the kind in the sphere of information-communication technologies are of great help to this development. In the meantime the processes of stream convergation on innovation and technological levels are taking place. At the same time huge waves of Western mass culture are filling up the world information space, crossing the national borders not asking neither governments nor people of these countries whether they want their presence in the information spaces of these countries, regions and even continents.

Observing the nature of the new concept "mediacracy", which appeared in the West European scientific reflection and in journalism for identifying those who not only have as their property media and information-communication conglomerates ("multimedia 
empires"), but concentrated on huge media power that converged into political power. As a result of this research, for the first time in the science of communication the author creates the typology of global mediacracy. And it leads to the analysis of new forms and methods of media empires' expansion permitting to come to the conclusion that expansion of mediacracy is one of the traits of the growth of global media and their world domination at the beginning of the third millennium.

In the 3rd chapter the author analyses global satellite news as a new stage of global communication. The author explores global satellite news from their birth in 1980, when CNN started its functioning, till nowadays comparing it with BBC World and Al Jazeera International. While exploring the changes in their reporting, Olga Zernetska focuses on interactivity of global television channels that radically changes the world media landscape opening a discussion on the transformations of global information-communication processes in their news aspect into the domain of international relations' players. Thus the analyses is turned to theoretical and practical foundations of the rise of the global blogosphere as a new arena of political struggle covering the main forms and methods of using blogosphere during Barack Obama's presidential campaign and the use of online possibilities during parliamentary elections in Great Britain as case studies. The specificity of the models of national elections in the USA and Great Britain together with some other countries of the world is represented as a result of the analysis

The $4^{\text {th }}$ chapter comes with the analysis of different strategies of survival of global media empires and telecommunication companies in the period of global financial and economic crisis. The chapter, which is fully built on case studies, gives a profound picture of different sectors of information-communication economy. The analysis of the coverage of the global financial and economic crisis by the national media integrates interdisciplinary approaches, within which the discourse study is conducted. In fact the discourse of media coverage, as the author shows, gives cutting-edge arguments for understanding the situation specifically in the USA, where the crisis began. The analysis of economic and political motivations of this phenomenon are combined proving their close connection. The models of survival by media empires in the situation of the crisis are represented and discussed. Within it the author dwells on aggressive strategies in this struggle. She also distinguishes the peculiarities of Latin American information and communication space in the period of global crisis. Besides, the chapter gives special attention to the Internet, which became in the time of crisis a new and very attractive kind of property for different multimillionaires and billionaires from mediacracy. She provides the insight into new mega trend in competition for the internet (cloud computing). Finally, the analysis of the development of media and ITC in Ukraine in the period of transition is being discussed with recommendations how to overcome drawbacks in its functioning added. 
The $5^{\text {th }}$ chapter provides an illuminating analysis of the different aspects of cyber security of the era of global communication, where the attention is paid to the strategies of cyber security of the USA. The concepts of cyber security, cyber space, cyber-attack, cyber operations, cyber intrusion, net, Internet and some others are specified. The main state documents dealing with the issues of cyber security of the USA from 2003 to nowadays are also under discussion in this chapter, which give ground to make conclusions on the evolution of the strategies of cyber space in the USA. The chapter also brings evidence to the fact that ruling elite understands very well the importance of the exponential development of national cyber space for wellbeing of the United States as well as the growing threats to its cyber security. Social networks and cyber security of the individual is also discussed here, just as social networks as MySpace, FriendWise, Yahoo!, 36o, Classmates, Facebook. The issues of saving privacy on social networks, saving the right of liberty of speech are also considered here.

Finally, the 6th chapter deals with global communication in the context of sustainable development. The author discusses the history of discourse of the scientific metaphor "digital divide" and the way it entered the Ukrainian scientific and political discourse, together with the challenges and threats of the global digital divide. The focus on the tendencies, which require solutions as how to close global digital divide. Different media formats in global communication ae discussed with the aim to build a typology on how the issues of sustainable development in global information and communication space are covered.

As we see, the author provides a unique insight into the development of the complex sphere of global communication integrating different perspectives into her analysis. As a result the interested reader can built a certain idea of the world processes under development just as the research community can witness an interesting, productive, and integrative research of a relatively new field of study.

Irina Oukhvanova

\section{Bibliography:}

ZERNEC'KA, O.: Hlobal'na komunìkacìja. Kyjiv: Naukova dumka, 2017.

https://doi.org/10.5817/0S2019-2-9

\section{O slovanském slovosledu z diachronního pohledu}

KREJČOVÁ, E. Slovosledné změny v bulharských a srbských evangelních památkách $z$ 12. a 13. století. Spisy FF MU, sv. 450. Brno: Masarykova univerzita, 2016, 144 s., ISBN 978-80-210-8338-7. 